\title{
Isolation, cloning and molecular characterization of a thermotolerant xylanase from Streptomyces sp. THW31
}

\author{
Thayat Sriyapai ${ }^{1}$, Peechapack Somyoonsap ${ }^{2}$, Supatra Areekit ${ }^{3}$, Paisarn Khawsak ${ }^{4}$, \\ Arda Pakpitcharoen ${ }^{4}$ and Kosum Chansiri ${ }^{4 *}$ \\ ${ }^{1}$ Faculty of Environmental Culture and Ecotourism, Srinakharinwirot University, Bangkok 10110, Thailand. \\ ${ }^{2}$ Department of Biology, Faculty of Sciences, Srinakharinwirot University, Bangkok 10110, Thailand. \\ ${ }^{3}$ Innovative Learning Center, Srinakharinwirot University, Bangkok 10110, Thailand. \\ ${ }^{4}$ Department of Biochemistry, Faculty of Medicine, Srinakharinwirot University, Bangkok 10110, Thailand.
}

Accepted 12 December, 2012

\begin{abstract}
A xylan-degrading Streptomyces sp. THW31 was isolated from rubbish compost in Thailand. Analysis of a genomic library of nucleotide sequences from Streptomyces sp. THW31 revealed that the complete open reading frame (ORF) of xylanase (xInW31) was $999 \mathrm{bp}$, and this gene encoded a member of the glycosyl hydrolase family 11 . Sequence homology of the predicted amino acid sequence encoded by xInW31 demonstrated that the enzyme consists of a signal peptide, catalytic and substrate-binding domains. The XInW31 enzyme shared the highest identity $(90 \%)$ to a xylanase family 11 member from Streptomyces lividans TK24. Cloning and expression of xInW31 in Escherichia coli resulted in the production and purification of a $31.0 \mathrm{kDa}$ enzyme. Purified XInW31 show the highest activity at pH 6.0 and at a temperature 65 to $70^{\circ} \mathrm{C}$. Enzyme stability tests indicated that XInW31 retained its activity over a broad $\mathrm{pH}$ range (5.0 to 11.0) and at temperatures reaching $60^{\circ} \mathrm{C}$ for $2 \mathrm{~h}$. Purified XInW31 also exhibited endo-1,4- $\beta$-xylanase activity using xylan as a substrate and bound to insoluble xylan. Hydrolysis of xylan by the xylanase yielded xylobiose as the principal product.
\end{abstract}

Key words: Gene expression, hemicellulase, Streptomyces, xylan, xylanase.

\section{INTRODUCTION}

The lignocellulosic plant cell wall is comprised of the three major components (cellulose, hemicellulose and lignin). Xylan, a major component of hemicelluloses, is a heteropolysaccharide that contains a backbone of $\beta-1,4-$ linked xylopyranose units with substituent groups of acetyl, arabinosyl and glucuronosyl residues (Puls, 1997). Endoxylanases (1,4- $\beta$-D-xylan xylanohydrolase; E.C 3.2.1.8) randomly hydrolyze $1,4-\beta-D-x y l o s i d i c$ linkages of the main chain of xylan to xylooligosaccharides, which are then further degraded to xylose monomers from the non-reducing end of xylooligosaccharides and xylobiose by $\beta$-D-xylosidase

${ }^{\star}$ Corresponding author. E-mail: kosum@swu.ac.th. Tel: +662664-1000(4605). Fax: +662-664-1000(4618).
(EC 3.2.1.37) (Blely et al., 1997). The side groups that are present in heteroxylan are liberated by accessory enzymes, such as $\alpha$-L-arabinofuranosidases (EC3.2.1.55), $\alpha$-D-glucuronidases (EC 3.2.1.139) and acetyl xylan esterases (EC 3.1.1.72).

Xylanases are fast becoming a major group of industrial enzymes with significant application in the paper and pulp industry. These enzymes hydrolyze xylan and facilitate the release of lignin from paper pulp, which helps to reduce the use of toxic chlorine as a bleaching agent (Viikari et al., 1994). Potential applications of xylanase also include the bioconversion of xylan in lignocellulosic material and agro-wastes to fermentative sugar and food products (Coughlan and Hazlewood, 1993). Moreover, the xylan hydrolysis products can be subsequently converted to liquid fuel (Dodd and Cann, 2009). Many thermotolerant microorganisms including 
bacteria (actinomycetes, eubacteria and archaea) and fungi are known to produce thermostable xylanases. In addition, Streptomyces has been reported as the dominant xylanolytic species of actinomyces producing the hemicellulose degradation enzymes (Subramaniyan and Prema, 2002).

The cellulase free-family 11 xylanases containing cellulose binding domains (CBDs) or xylans binding domains (XBDs) are normally used in hydrolysis applications in which low-molecular-mass xylanase is effective for penetrating and increasing destruction by enzyme attachment to its substrate (Gill, 1999). Thermoand alkaline-stable xylanases from several Streptomyces species have been cloned, sequenced and biochemically characterized (Wang et al., 2007; Georis et al., 2000; Li et al., 2009; Shin et al., 2009). However, there are few reports regarding the cloning and expression of xylanase gene from thermotolerant Streptomyces that can produce many hemicellulases using agricultural waste materials as substrates.

In this study, the extracellular thermophilic hemicellulase-producing Streptomyces sp. strain THW31 was isolated and catalytic domains including CBD type 2 (CBD2) sequences in the xylanase enzyme were identified and analyzed. The deduced amino acid sequences suggested that this thermotolerant xylanase was classified in xylanase family 11 . The xylanase gene was cloned and expressed in Escherchia coli and the expressed recombinant enzyme was purified and characterized.

\section{MATERIALS AND METHODS}

\section{Vectors, reagents and mediums}

E. coli TOP10 (Invitrogen, Carlsbad, CA, USA) and pZErO-2 (Invitrogen) were used as the host and vector, respectively, for the construction of a genomic library from Streptomyces sp. THW31. The pGEM $^{\circledR}$-T easy vector (Promega, Madison, WI, USA) and $E$. coli DH5 $\alpha$ (Takara, Kyoto, Japan) were used for subcloning. pQE80L (Qiagen, Valencia, CA, USA) and E. coli Rosetta gami B (DE3) (Novagen, Madison, WI, USA) were used for cloning and expression of a xylanase gene. Xylan-degrading bacterial were grown in an actinomyces medium (Techapun et al., 2001) and in Luria Bertani (LB) medium at $60^{\circ} \mathrm{C}$ for three to five days. E. coli were grown in LB medium at $37^{\circ} \mathrm{C}$ for 18 to $24 \mathrm{~h}$. Oat spelt xylan, birchwood xylan, beechwood xylan and $p$-nitrophenyl derivatives were purchased from Sigma-Aldrich (St. Louis, MO., USA). AZCLoat spelt xylan and xylooligosaccharides were purchased from Megazyme Company (Bray, Ireland). Corncob, corn husk, sugarcane bagasse and rice straw were cut to a small size, grounded with a blender and transferred through a sieve to collect 40-mesh particles, which were washed three times with warm distilled water, dried at $50^{\circ} \mathrm{C}$ and used as inducers for hemicellulases production.

\section{Microorganism isolation}

Streptomyces sp. strain THW31 was collected from rubbish compost in Thailand and isolated using a minimal xylan medium.
The $0.1 \mathrm{~g}$ soil sample was transferred to $100 \mathrm{ml}$ of minimal xylan medium in a $1000 \mathrm{ml}$ Hinton flask and incubated on a rotary shaker at $200 \mathrm{rpm}$ at $60^{\circ} \mathrm{C}$ for 5 days. The minimal xylan medium contained $10 \mathrm{~g}$ oat spelt xylan, $0.2 \mathrm{~g}$ yeast extract, $1.0 \mathrm{~g}\left(\mathrm{NH}_{4}\right)_{2} \mathrm{SO}_{4}$, $1.6 \mathrm{~g} \mathrm{~K}_{2} \mathrm{HPO}_{4}, 0.2 \mathrm{~g} \mathrm{KH}_{2} \mathrm{PO}_{4}, 0.2 \mathrm{~g} \mathrm{MgSO}_{4} .7 \mathrm{H}_{2} \mathrm{O}, 0.1 \mathrm{~g} \mathrm{NaCl}, 0.02$ g $\mathrm{CaCl}_{2} .2 \mathrm{H}_{2} \mathrm{O}, 0.01 \mathrm{~g} \mathrm{FeSO}_{4} .7 \mathrm{H}_{2} \mathrm{O}, 0.0005 \mathrm{~g} \mathrm{Na} \mathrm{MoO}_{4} .2 \mathrm{H}_{2} \mathrm{O}$, $0.0005 \mathrm{~g} \mathrm{Na}_{2} \mathrm{WO}_{4} .2 \mathrm{H}_{2} \mathrm{O}$ and $0.0005 \mathrm{~g} \mathrm{MnSO}_{4}$ in $1 \mathrm{~L}$ of distill water and was adjusted to $\mathrm{pH} 7.0$. The diluted enriched culture $(0.1 \mathrm{ml})$ was spread on a minimal xylan agar plate and incubated at $60^{\circ} \mathrm{C}$ for 5 days. Clear zones generated by xylan-degrading strains were visualized using $0.1 \%$ Congo red and destained with $1 \mathrm{M} \mathrm{NaCl}$. The strongest xylan-degrader strain THW31 was selected and used for taxonomic identification based on 16S rDNA analysis using the method of Keiichi et al. (2000). A permanent stock of strain THW31 was generated by suspending growing cells in culture medium containing $15 \%$ glycerol and storing the resulting stock at $-80^{\circ} \mathrm{C}$.

\section{Induction of hemicellulose-degrading enzymes production using agricultural waste}

The actinomyces medium that contained $1.5 \mathrm{~g} / \mathrm{l} \mathrm{KH}_{2} \mathrm{PO}_{4}, 2 \mathrm{~g} / \mathrm{l}$ $\mathrm{K}_{2} \mathrm{HPO}_{4}, 1.4 \mathrm{~g} / \mathrm{l}\left(\mathrm{NH}_{4}\right)_{2} \mathrm{SO}_{4}, 2 \mathrm{~g} / \mathrm{l}$ yeast extract, $1 \mathrm{~g} / \mathrm{l}$ peptone, $2 \mathrm{ml}$ Tween 80 and $1 \mathrm{ml}$ trace element solution was supplemented with agricultural waste and used for hemicellulase enzyme production. Streptomyces sp. strain THW31 was cultured in $50 \mathrm{ml}$ of actinomyces medium containing $3 \%$ of each kind of agriculture waste such as corncob, corn husk, rice straw and sugarcane bagasse. Each culture was inoculated in $250 \mathrm{ml}$ Hinton flasks and shaken at $60^{\circ} \mathrm{C}$ for five days. The $3 \%$ of oat spelt xylan was added to the same medium for hemicellulase enzyme production. The culture supernatants were collected and assayed for xylanase, $\beta$ xylosidase, $\alpha$-arabinofuranosidase and acetyl xylan esterase activities.

\section{Enzymes assay}

Xylanase activity was determined by the detection of reducing sugars that were liberated from $1 \%$ oat spelt xylan using the method of Bailey et al. (1992). The reaction mixture $(0.7 \mathrm{ml})$ was consisted of $0.1 \mathrm{ml}$ enzyme and $0.6 \mathrm{ml} 1 \%$ xylan in Mcllvaine buffer $\left(\mathrm{pH}\right.$ 6.0). After incubation for $10 \mathrm{~min}$ at $65^{\circ} \mathrm{C}$, the reaction was inactivated for $5 \mathrm{~min}$ at 95 to $100^{\circ} \mathrm{C}$ and immediately placed on ice. Reducing sugars were estimated using the dinitrosalicylic acid method. Xylose was used as a standard for the xylanase activity test. One unit of enzyme activity was defined as the amount of enzyme releasing $1 \mu$ mole reducing sugar per min.

$\beta$-xylosidase, $\alpha$-arabinofuranosidase and acetyl xylan esterase activities were measured using $p$-nitrophenyl- $\beta-D$-xylopyranoside (pNPX), p-nitrophenyl- $\alpha$-L-arabinofuranoside (pNPA) and $p$ nitrophenyl-acetate (pNA) as the substrate, respectively. All assay mixture consisted of $0.9 \mathrm{ml}$ of $\mathrm{p}$-nitrophenyl-derivative $(2 \mathrm{mM})$ in $100 \mathrm{mM}$ Mcllvaine buffer ( $\mathrm{pH} \mathrm{6.0)}$ and an appropriate volume of enzyme sample to result in a final volume of $1.0 \mathrm{ml}$. The reaction mixture was incubated at $65^{\circ} \mathrm{C}$ for 15 min then $1.0 \mathrm{ml}$ of $0.5 \mathrm{M}$ sodium carbonate $\left(\mathrm{Na}_{2} \mathrm{CO}_{3}\right)$ was added to terminate the reaction. The amount of nitrophenol liberated from a substrate was determined by absorbance measurements at $410 \mathrm{~nm}$. One unit of enzyme activity was defined as the amount of an enzyme to yield 1 $\mu$ mole nitrophenol per min.

Genomic DNA library construction, PCR and nucleotide sequence analysis

Chromosomal DNA from Streptomyces sp. strain THW31 was extracted according to a modification of the method of Marmur 
(1961). The purified chromosomal DNA was partially digested with Sau3Al at $37^{\circ} \mathrm{C}$ for different lengths of time to obtain a size range of 2 to $10 \mathrm{~kb}$. The linearized BamHI-digested pZErO-2 vector was ligated to the Sau3AI-digested chromosomal DNA and transformed into competent $E$. coli TOP10 cells. Low salt LB agar that was supplemented with $0.5 \%$ AZCL-oat spelt xylan, $1 \mathrm{mM}$ of isopropyl$\beta$-D-thiogalactopyranoside (IPTG) and $50 \mu \mathrm{g} / \mathrm{ml}$ kanamycin was used to screen for transformants that contained xylan-degrading activity. The plates were incubated at $37^{\circ} \mathrm{C}$ for 24 to $48 \mathrm{~h}$, and positive transformants were identified by the presence of blue zones derived from the hydrolyzed AZCL-xylan around the transformants. Positive colonies were selected and re-analyzed for xylanse activity using the same procedure. The plasmid harboring the xylanase gene was designated as PZErO-X3. The nucleotide sequences of the inserted DNA were analyzed by using primer walking and the open reading frame (ORF) was analyzed using $\mathrm{NCBI} \quad$ sequence analysis (http://www.ncbi.nlm.nih.gov/gorf/gorf.html). A homology search was performed using the GenBank BLAST program (http://blast.ncbi.nlm.nih.gov/Blast.cgi) and multiple alignments were carried out with the CLUSTAL W2 program (http://www.ebi.ac.uk/Tools/clustalw2/). The signal peptide was predicted using the SignalP 3.0 server (http://www.cbs.dtu.dk/services/SignalP/). Three dimensional models of xylanase were generated using the CPHmodels 3.2 server (http://www.cbs.dtu.dk/services/CPHmodels/).

The xylanase gene ORF consisted of a 123 base pair (bp) signal peptide and $876 \mathrm{bp}$ nucleotide sequences of the mature xylanase. The predicted mature xylanase gene was amplified by PCR using KOD Plus Taq Polymerase (Toyobo, Osaka, Japan) in the presence of $5 \%$ dimethyl sulfoxide. Primers (F1, 5'CGGGATCCGGCACGGTCGTCACGACCAAC-3' and R1, 5'CCAAGCTTTCAGCCCGCGCTGCAGGAGACC-3'; BamHI and Hindll restriction sites are underlined in $F 1$ and $R 1$, respectively) were designed based on the xylanase ORF and were used for xylanase gene expression in E. coli. All PCR products were amplified under the following conditions: denaturation at $98^{\circ} \mathrm{C}$ for $5 \mathrm{~min}$ followed by 35 cycles of denaturation at $94^{\circ} \mathrm{C}$ for $15 \mathrm{~s}$, annealing at $65^{\circ} \mathrm{C}$ for $1 \mathrm{~min}$ and polymerization at $68^{\circ} \mathrm{C}$ for $1 \mathrm{~min}$ with a final extension at $72^{\circ} \mathrm{C}$ for 7 min. A polyA tail was added to PCR products using 10X A-Attachment Mix. The resulting products were then purified and ligated into a PGEM $^{\circledR}-T$ vector and named pGEM-xInW31. These plasmids contained restriction sites for cloning into $\mathrm{PQE} 80 \mathrm{~L}$.

\section{Expression and purification of the xylanase gene}

The xylanase gene fragment in pGEM-xInW31 was liberated by digestion with $\mathrm{BamHI}$ and Hindlll, and subsequently ligated into pQE80L expression vector. The pQE-xInW31 was then transformed into $E$. coli Rosetta-gami B (DE3) and the transformants were cultured on LB agar supplemented with ampicillin $(100 \mu \mathrm{g} / \mathrm{ml})$ and kanamycin $(34 \mu \mathrm{g} / \mathrm{ml})$ at $37^{\circ} \mathrm{C}$ for $24 \mathrm{~h}$. Xylanase activities of positive transformants were screened on LB agar supplemented with $0.5 \%$ (w/v) AZCL-oat spelt xylan, $1 \mathrm{mM} \mathrm{IPTG}$ and $100 \mu \mathrm{g} / \mathrm{ml}$ of ampicillin. Selected $E$. coli transformants were grown in LB supplemented with $100 \mu \mathrm{g} / \mathrm{ml}$ of ampicilin and $34 \mu \mathrm{g} / \mathrm{ml}$ of kanamycin until the cultures reached an optical density at $600 \mathrm{~nm}$ 0.6 to 0.8 . IPTG was added to a final concentration of $1 \mathrm{mM}$, and the culture was cultivated at $37^{\circ} \mathrm{C}$ for $6 \mathrm{~h}$. The cells were collected by centrifugation at $5000 \mathrm{rpm}$ for $5 \mathrm{~min}$ and washed twice with 0.5 $\mathrm{M} \mathrm{NaCl}$ prior to cell disruption by sonication. The suspension was centrifuged at $12000 \mathrm{rpm}$ for $30 \mathrm{~min}$ to remove cell debris and unlysed cells. The resulting supernatant was purified by immobilized metal ion affinity chromatography (IMAC) on a Sepharose 6 fast flow column (GE Healthcare, Japan) according to the manufacturer's instruction. The purity of fractions containing xylanase activity was confirmed by sodium dodecyl sulphate (SDSPAGE).

\section{Enzyme characterization}

The purified xylanase enzyme expressed in E. coli (XInW31) was used for enzyme characterizations. The optimum $\mathrm{pH}$ was determined using three different buffers that spanned $\mathrm{pH} 3.0$ to 11.0 at a final concentration of $100 \mathrm{mM}$ : Mcllvaine buffer $(\mathrm{pH} 3.0$ to 7.0); Tris-HCl buffer (pH 7.0 to 9.0) and glycine- $\mathrm{NaOH}(\mathrm{pH} 9.0$ to 11.0). The optimum temperature was determined by incubating purified enzymes in $100 \mathrm{mM}$ Mcllvaine buffer $(\mathrm{pH} \mathrm{6.0)}$ at different temperatures ranging from of 30 to $100^{\circ} \mathrm{C}$. Xylanase activity assays were achieved according to the method of Bailey et al. (1992) and the relative activities of enzyme served as a control. The stability at different $\mathrm{pHs}$ (3.0 to 11.0) was determined by initially incubating the diluted enzyme in buffers of each $\mathrm{pH}$ at $60^{\circ} \mathrm{C}$ for $1 \mathrm{~h}$ then determining the residual activities at optimum temperature under the standard assay conditions. Thermal stability was determined by pre-incubation of the enzyme in $100 \mathrm{mM}$ Mcllvaine buffer $(\mathrm{pH} \mathrm{6.0)}$ at various temperatures ranging from 50 to $70^{\circ} \mathrm{C}$ for $2 \mathrm{~h}$ prior to the addition of substrate. The residual activities were determined at optimum temperature under the standard assay conditions.

The effect of metal ions (1 mM) and the influence of other agents on xylanase activity were investigated by pre-incubation of the purified enzyme in the presence of each metal ion and other agent in parallel with an untreated control. Purified enzyme was preincubated in $100 \mathrm{mM}$ Mcllvaine buffer $(\mathrm{pH} \mathrm{6.0})$ at $60^{\circ} \mathrm{C}$ for $1 \mathrm{~h}$. The residual activities at optimum temperature under the standard assay conditions were then determined. Substrate specificity of the purified enzyme was determined using various xylans as substrates.

\section{Thin layer chromatography (TLC) of xylan hydrolysis products}

Purified enzyme (5 U/mg) was incubated in a reaction mixture including a substrate of commercial xylans $(50 \mathrm{mg} / \mathrm{ml})$ and $100 \mathrm{mM}$ Mcllvaine buffer $\left(\mathrm{pH} \mathrm{6.0)}\right.$ at $50^{\circ} \mathrm{C}$. An aliquot of the reaction mixture was withdrawn at appropriate intervals and the reaction was stopped by boiling for $5 \mathrm{~min}$. The mixture was centrifuged to remove precipitates and subjected to TLC (silica gel $60 \mathrm{~F}_{254}$, Merck Ltd., Tokyo, Japan). TLC plates were developed with chloroform-acetic acid- $\mathrm{H}_{2} \mathrm{O}(6: 7: 1, \mathrm{v} / \mathrm{v} / \mathrm{v})$ and sprayed with a mixture of methanolsulfuric acid $(95: 5, \mathrm{v} / \mathrm{v})$ followed by heating at $150^{\circ} \mathrm{C}$ in an oven until spots appeared.

\section{Binding assay}

The preparation of insoluble oat spelt xylan was performed by an alkali treatment method as previously reported (Ghangas et al., 1989). Binding experiments were performed by adding the purified enzyme $(5 \mathrm{U} / \mathrm{mg})$ to various amounts of avicel or insoluble oat spelt xylan in $1.0 \mathrm{ml}$ of $50 \mathrm{mM}$ Tris- $\mathrm{HCl}(\mathrm{pH} 7.0)$ in $1.5 \mathrm{ml}$ microcentrifuge tubes. Samples were placed at $60^{\circ} \mathrm{C}$ for $1 \mathrm{~h}$ and then centrifuged. The xylanase activity in the supernatant was determined by standard method and the activity lost from the supernatant was assumed to be the bound enzyme.

\section{SDS-PAGE and zymography}

SDS-PAGE was performed using a $12.5 \%$ polyacrylamide gel according to the method of Laemmli (1970). Protein was visualized by Coomassie Brilliant Blue (CBB) staining. Zymography was performed on SDS-PAGE with a $12.5 \%$ polyacrylamide gel that was 
Table 1. Induction of hemicellulase-related enzymes of Streptomyces sp. THW31 by xylan-containing agricultural wastes.

\begin{tabular}{lcccc}
\hline Carbon source (3\%) & $\begin{array}{c}\text { Xylanase } \\
(\mathbf{U} / \mathbf{m l})\end{array}$ & $\begin{array}{c}\beta \text {-Xylosidase } \\
(\mathbf{U} / \mathbf{m l})\end{array}$ & $\begin{array}{c}\alpha \text {-Arabinofuranosidase } \\
(\mathbf{U} / \mathbf{m l})\end{array}$ & $\begin{array}{c}\text { Acetyl xylan esterase } \\
(\mathbf{U} / \mathbf{m l})\end{array}$ \\
\hline Oat spelt xylan & $28.6 \pm 1.2$ & $0.12 \pm 0.011$ & $0.16 \pm 0.014$ & $0.13 \pm 0.015$ \\
Corn cob & $30.5 \pm 1.5$ & $0.16 \pm 0.004$ & $0.12 \pm 0.023$ & $0.15 \pm 0.011$ \\
Corn hull & $12.8 \pm 1.3$ & $0.08 \pm 0.001$ & $0.09 \pm 0.001$ & $0.05 \pm 0.0013$ \\
Cane bagasse & $25.7 \pm 2.1$ & $0.07 \pm 0.001$ & $0.07 \pm 0.003$ & $0.06 \pm 0.005$ \\
Rice straw & $19.1 \pm 2.0$ & $0.05 \pm 0.003$ & $0.08 \pm 0.002$ & $0.03 \pm 0.001$ \\
Xylose & $2.5 \pm 0.05$ & $\mathrm{ND}$ & $\mathrm{ND}$ & $\mathrm{ND}$ \\
Glucose & $0.9 \pm 0.01$ & $\mathrm{ND}$ & $\mathrm{ND}$ & $\mathrm{ND}$ \\
\hline
\end{tabular}

Streptomyces sp. THW31 was cultivated at $60^{\circ} \mathrm{C}$ for five days on actinomyces medium containing different substrate. Small amount of xylanase activity $(0.9$ to $2.5 \mathrm{U} / \mathrm{ml})$ was observed, when xylose and glucose were used as carbon source in actinomyces medium. The results are expressed as mean \pm standard deviation in culture supernatants from three independent experiments. ND, not done.

supplemented with $0.2 \%$ oat spelt xylan. The xylanase activity on the gel was detected following the method of Nakamura et al. (1993) with slight modification. SDS was removed from SDS-PAGE gels by gentle shaking in $20 \%(\mathrm{v} / \mathrm{v})$ isopropanol at $4^{\circ} \mathrm{C}$ for $1 \mathrm{~h}$, and the gel was washed twice with distilled water to remove isopropanol. The washed gel was incubated in $100 \mathrm{mM}$ Mcllvaine buffer $(\mathrm{pH} 6.0)$ at $60^{\circ} \mathrm{C}$ for $1 \mathrm{~h}$, stained with $0.1 \%(\mathrm{w} / \mathrm{v})$ Congo Red for 30 min to react with the remaining xylan and washed twice in 1 $\mathrm{M} \mathrm{NaCl}$ at room temperature for $10 \mathrm{~min}$ with shaking. When a destained band appeared, the gel was fixed with $0.5 \%(\mathrm{v} / \mathrm{v})$ acetic acid.

\section{RESULTS}

\section{Screening and identification of a xylan-degrading Streptomyces strain}

The Streptomyces strain THW31 that was capable of xylan degradation was isolated from rubbish compost and identified by $16 \mathrm{~S}$ rDNA analysis, as described in the Materials and Methods. Strain THW31 cells produced clear and strong halos on a minimal xylan agar plate that was incubated at $60^{\circ} \mathrm{C}$ for three days. The amplified $16 \mathrm{~S}$ rDNA fragment (approximately $1406 \mathrm{bp}$; accession no.GU929208) suggested that the strain was a Streptomyces species with $99.8 \%$ identity to S. rochei strain HBUM174096 (accession no. EU841560), $S$. enissocaesilis strain NRRL B-16365 (DQ026641), S. olivaceus (AB184730), Actinomycetales bacterium R10 (2010) strain R10 (HM007159). Thus, this strain was designated Streptomyces sp. strain THW31.

\section{Induction of hemicellulose-degrading enzymes by xylans}

Streptomyces sp. THW31 produced total xylanase activity such as xylanase, $\beta$-xylosidase, $\alpha$ arabinofuranosidase and acetyl xylan esterase in the culture supernatant when the cells were grown on an actinomycetes medium supplement with various agricultural wastes that contained xylan or commercially available xylan (oat spelt xylan) as a carbon source
(Table 1). The strain show significant xylanase activity when grown on all xylans, but the highest xylanase activity $(30.5 \mathrm{U} / \mathrm{ml})$ was obtained from cells grown with corncob as the xylan source. The strain also produced hemicellulases such as $\beta$-xylosidase, $\alpha$ arabinofuranosidase and acetyl xylan esterase, when the cells were grown on all carbon sources, with corncob serving as the best carbon source for enzymes production. However, cells grown with cane bagasse $(25.7 \mathrm{U} / \mathrm{ml})$ produced more xylanase compared with cells grown with rice straw $(19.1 \mathrm{U} / \mathrm{ml})$ or corn hull $(12.8 \mathrm{U} / \mathrm{ml})$ as the carbon source. Lower levels of xylanase production $(0.9$ and $2.5 \mathrm{U} / \mathrm{ml})$ were observed after growth with glucose and xylose, respectively.

\section{Cloning and sequencing analysis of a xylanase gene from Streptomyces sp. THW31}

A genomic library was constructed from Streptomyces sp. THW31 genomic DNA using a pZErO-2 vector and E. coli Top10 cells. A genomic library that consisted of approximately 8,000 transformants was obtained. From this library, a single transformant exhibited xylanase activity on low salt LB agar plates that were supplemented with $0.5 \%(\mathrm{w} / \mathrm{v})$ AZCL-oat spelt xylan, 1 $\mathrm{mM} \mathrm{IPTG}$ and $50 \mu \mathrm{g} / \mathrm{ml}$ kanamycin. The transformant that displayed positive xylanase activity was designated pZErO-X3 and contained a plasmid with an approximate insert size of $2.3 \mathrm{~kb}$. The nucleotide sequences of the xylanase gene ( $x \ln W 31)$ (Figure 1) show a complete ORF that was 999 bp in length (accession no. HQ286611). The xylanase ORF encoded a 333 amino acids was corresponded to a calculated molecular weight of $34,976 \mathrm{Da}$ with a $69 \% \mathrm{G}+\mathrm{C}$ content. The molecular weight of mature xylanase without signal peptide was $30,794 \mathrm{Da}$. According to the SignalP 3.0 program, XInW31 contained a signal peptide of 41 amino acids and a probable mature xylanase and CBD2 of 292 amino acids. Upon amino acid comparison, the conserved catalytic residues of XInW31 was Glu 128 and Glu 218. A ribosome binding site (5'-AGGAAG-3') was identified 10 
cccagggagcgggggttcgaaaatttcggaggactccaccgccctttccggtgcattcgatgagggctcgctcggtggtgagggggacg cctgtcgggggatggcttgagctgcgggttctttcctccggctccaccgtcggtggcgccgaaggtttcgaaatattcaccgaaactgt tgacgcttgatgggtgcaggtcaacactggcgccgttgtccgaaccccgtaggtccgetcaggaccetccggagaggaagcaccccccc

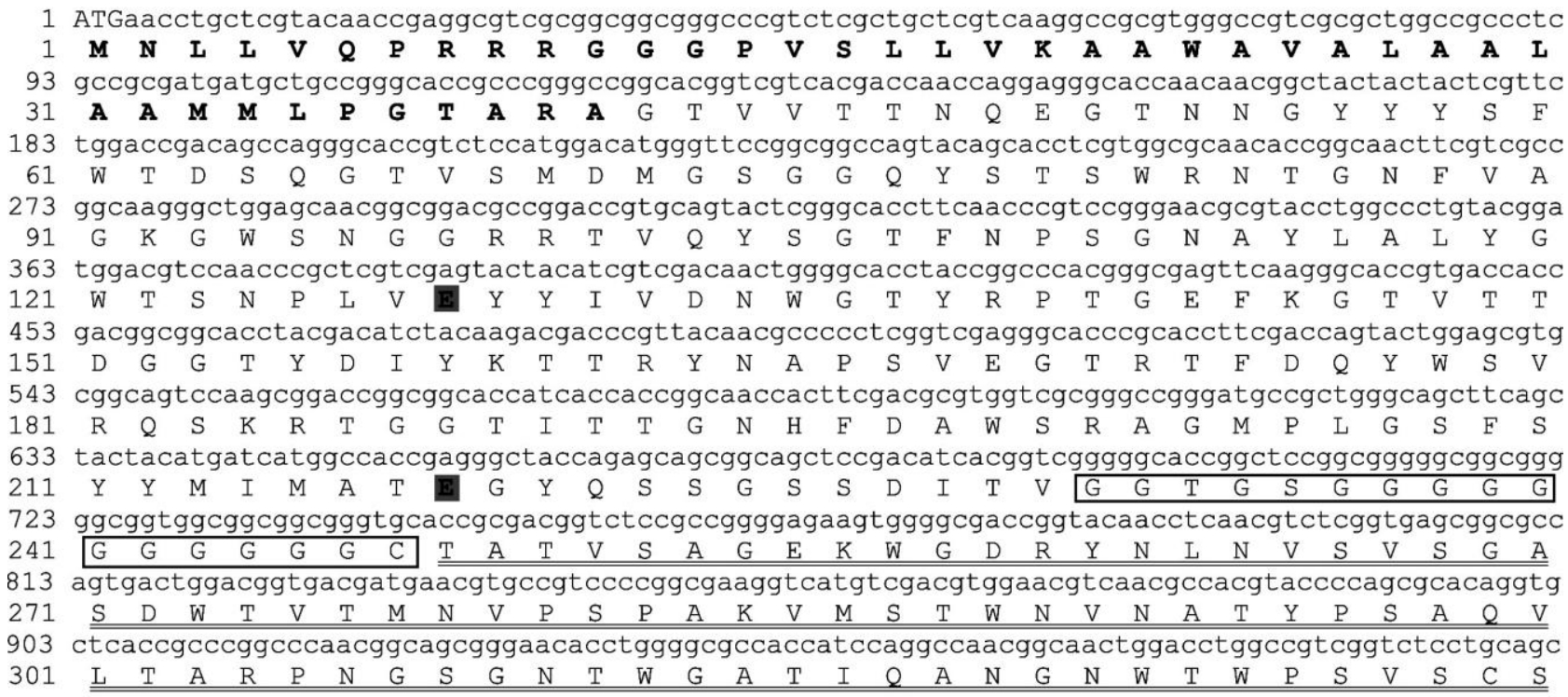

993 gcgggctga 999

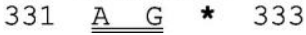

Figure 1. Nucleotide and deduced amino acid sequences of XInW31 xylanase from Streptomyces sp. THW31. The location of the ribosome-binding site is underlined and signal peptides are bold. The start codon is uppercase. The Gly-rich linker is boxed and the amino acid composing the CBD family 2 of XInW31 is double-underlined. Two conserved catalytic glutamic acids (E128 and E218) are shaded. The transcriptional stop codons were indicated by an asterisk.

bp upstream of the $x \ln W 31$ start codon (ATG) and the gene contained a TGA stop codon. Comparison of the probable full length xylanase with glycoside hydrolases family 11 indicated that XInW31 displayed varying high identities to xylanases from different organisms, including identity to S. lividans TK24 (90\%; ZP_05526520), S. viridosporus (76\%; AAF09501), S. thermoviolaceus (75\%; BAD02383), Nocardiopsis dassonvillei DSM 43111 (73\%; EEK35774), Thermobifida fusca (71\%; AAV64879), Thermopolyspora flexuosa (67\%; CAD48747) and Cellulomonas pachnodae (61\%; AAD54767). In addition, homology modeling prediction demonstrated that XInW31 model show the highest protein sequence and model structure similarity with xyl1 xylanase from Streptomyces sp. S38 (Wouters et al., 2001) (Figures 2a, b).

\section{Expression and purification of recombinant XInW31 from $E$. coli}

The gene products of pQE80L- $x \ln W 31$ was expressed and purified from E.coli Rosetta-gami B (DE3) and subsequently characterized. SDS-PAGE analysis demonstrated that purified XInW31 exhibited a clear band with a molecular weight of approximately $31.0 \mathrm{kDa}$.
Similarly, a positive band on a zymogram was observed at the same position as that was presented on the SDSPAGE gel (Figure 3). The highest specific activity of recombinant XInW31 was $463.8 \mathrm{U} / \mathrm{mg}$. The purification fold of recombinant XInW31 from each purification step was listed in Table 2. The data indicated that purification fold and recovery yield of XInW31 were 4.5 fold and $21.3 \%$, respectively.

\section{Characterization of XInW31}

The optimum $\mathrm{pH}$ of $\mathrm{XInW} 31$ was at $\mathrm{pH} 6.0$, and the enzyme was stable over a $\mathrm{pH}$ range of 4.0 to 11.0 after 1 $\mathrm{h}$ incubation at $60^{\circ} \mathrm{C}$ (Figure 4). Assays determining the optimum temperature for xylanase activity revealed that XInW31 shows the highest activity at 65 to $70^{\circ} \mathrm{C}$ (Figure 5). The enzyme was stable at $60^{\circ} \mathrm{C}$ and retained with approximately $53.7 \%$ activity after 120 min while incubation at $70^{\circ} \mathrm{C}$ for 30 min resulted in rapid decrease in enzyme stability and activity to $50.5 \%$ (Figure 6). A substrate specificity test indicated that XInW31 hydrolyzed the soluble oat spelt xylan (119.2\%), beech wood xylan (100\%), insoluble oat spelt xylan (82.5\%), and birch wood xylan (81.1\%) (Table 3). In contrast, XInW31 could not digest avicel, carboxymethyl cellulose 


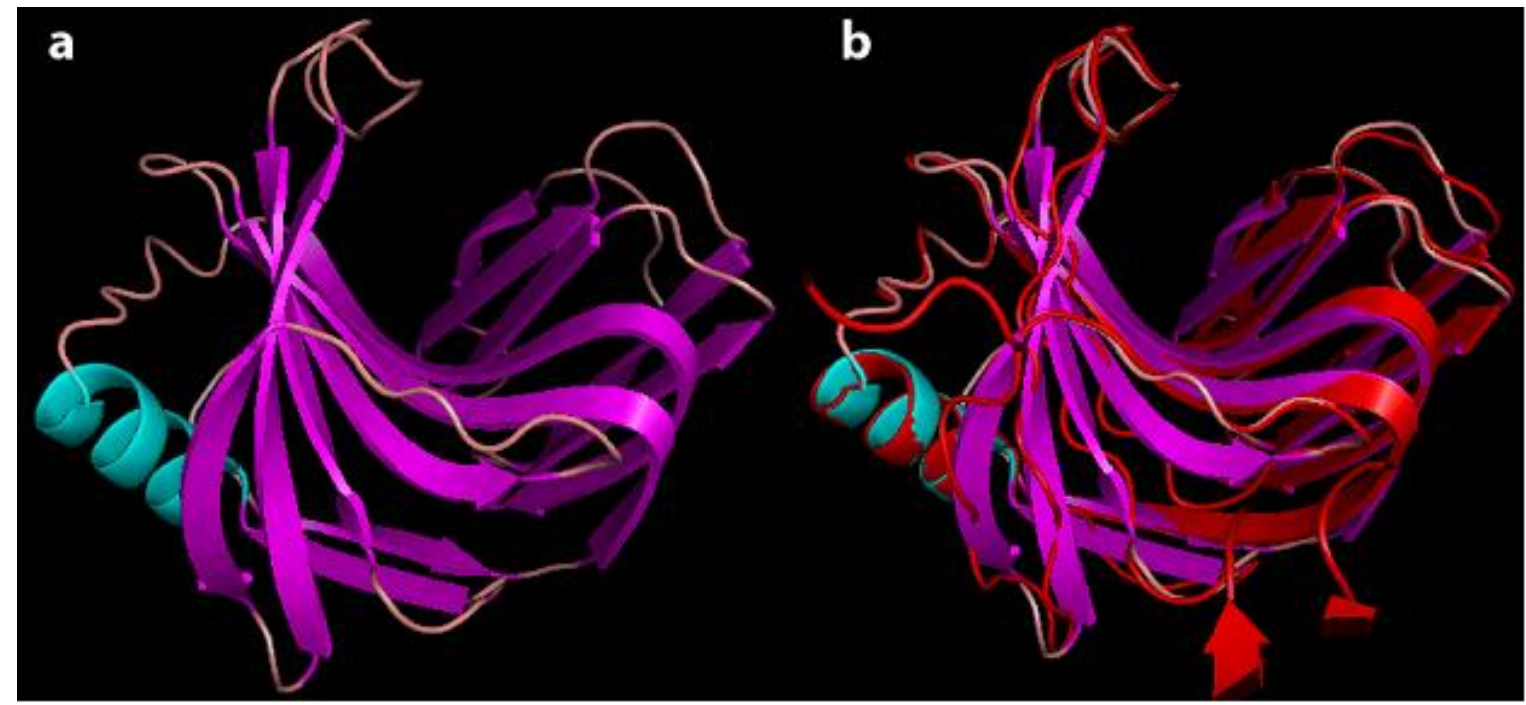

Figure 2. (a) Three-dimension structure modeling prediction of XynW31; (b) Superimposition of XynW31 (Pink) structure and template (Red) structure of Xyl1, a family 11 endo-xylanase from Streptomyces sp. S38 (Wouters et al., 2001).

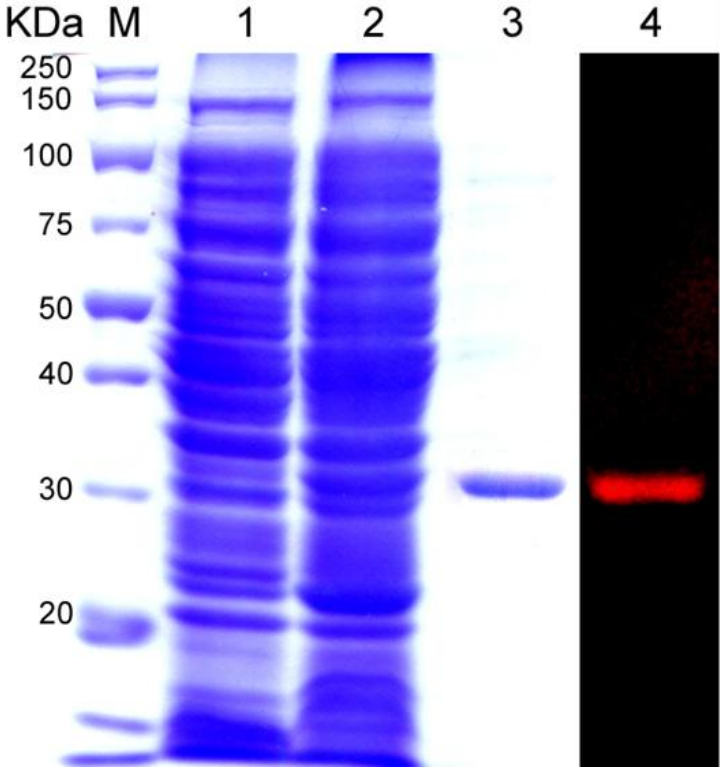

Figure 3. Coomassie blue-stained SDS-PAGE gel and zymogram of purified XInW31 from E. coli Rosetta gami (DE3) harboring PQE-xInW31. Lane M, molecular mass markers; lane 1, cell free extract of $E$. coli harboring $\mathrm{PQE} 80 \mathrm{~L}$; lane 2, cell free extract of $E$. coli harboring $\mathrm{pQE}-x \operatorname{In} W 31$; lane 3 , purified $\mathrm{X} \operatorname{InW} 31$ with IMAC; lane 4, zymogram of purified XInW31 by IMAC.

(CMC), glucomannan, spino gum, locust bean gum, pNPX, pNPA and pNA. These results suggested that recombinant $X \ln W 31$ was a cellulase-free xylanase and its CBD plays an important role in the hydrolysis of insoluble xylan.
According to an enzyme inhibition test in the presence of various metal ions and other reagents, XInW31 was totally and partially inhibited by $\mathrm{Hg}^{2+}$ and $\mathrm{Cu}^{2+}$, respectively. The other metal ions (monovalent and divalent ions) that were tested, SDS and ethylenediaminetetraacetic acid (EDTA) at a final concentration of $1 \mathrm{mM}$ did not inhibit xylanase activity (Table 4). Furthermore, XInW31 exhibited similar binding efficiency to insoluble oat spelt xylan and avicel (Figure 7). Regarding the rate of xylan hydrolysis activity of XInW31, the enzyme liberated xylooligosaccharides from oat spelt xylan in as short a time as 5 min (Figure 8). Based on this digestion, xylobiose was the final reaction product. Following an increased incubation time, xylose, xylobiose and xylotetraose production increased. These results suggested that this enzyme exhibited $\beta-1,4-$ endoxylanase activity.

\section{DISCUSSION}

In this study, a Streptomyces sp. strain THW31 was isolated from rubbish compost that exhibited strong xylanase activity on a minimal xylan agar plate. The strain was subsequently identified as Streptomyces sp. strain THW31 based on 16S rDNA analysis and was closely related to $S$. rochei, $S$. enissocaesilis and $S$. olivaceus. Streptomyces sp. strain THW31 produced the highest xylanase activity at a temperature of $60^{\circ} \mathrm{C}$. Actinomycete xylanases that have been studied so far, particularly those from Streptomyces genus, were mainly from thermophilic strains. Streptomyces sp. was reported to produce different enzymes with a wide variety of characteristics. However, comparatively little information 
Table 2. Summary of the purification of $X \ln W 31$.

\begin{tabular}{lccccc}
\hline Purification step & Total activity $(\mathbf{U})$ & Total protein $(\mathbf{m g})$ & Specific activity (U/mg) & Purification (fold) & Yield (\%) \\
\hline Cell-free extract & 2608.5 & 25.3 & 103.1 & 1.0 & 100.0 \\
IMAC & 556.6 & 1.2 & 463.8 & 4.5 & 21.3 \\
\hline
\end{tabular}

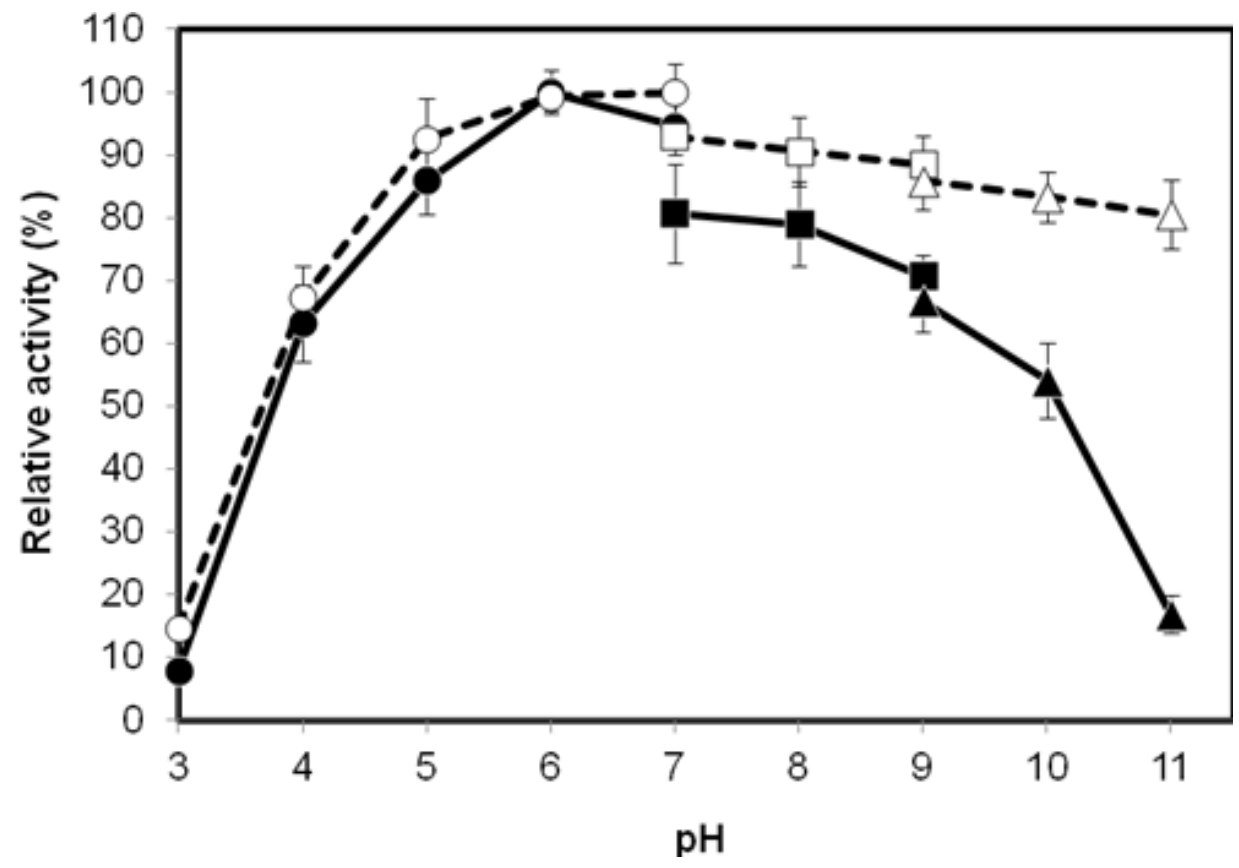

Figure 4. Effect of $\mathrm{pH}(-)$ and $\mathrm{pH}$ stability (…) on xylanase activity assayed at $60^{\circ} \mathrm{C}$ for $1 \mathrm{~h}$. The xylanase acitivity was performed in buffers ranging from $\mathrm{pH} 3.0$ to 11.0 . Symbols used: solid and open circles, Mcllvaine buffer for pH 3.0 to 7.0; solid and Open Square, Tris- $\mathrm{HCl}$ buffer for $\mathrm{pH} 7.0$ to 9.0 and solid and open triangles, glycine- $\mathrm{NaOH}$ for $\mathrm{pH} 9.0$ to 11.0 .

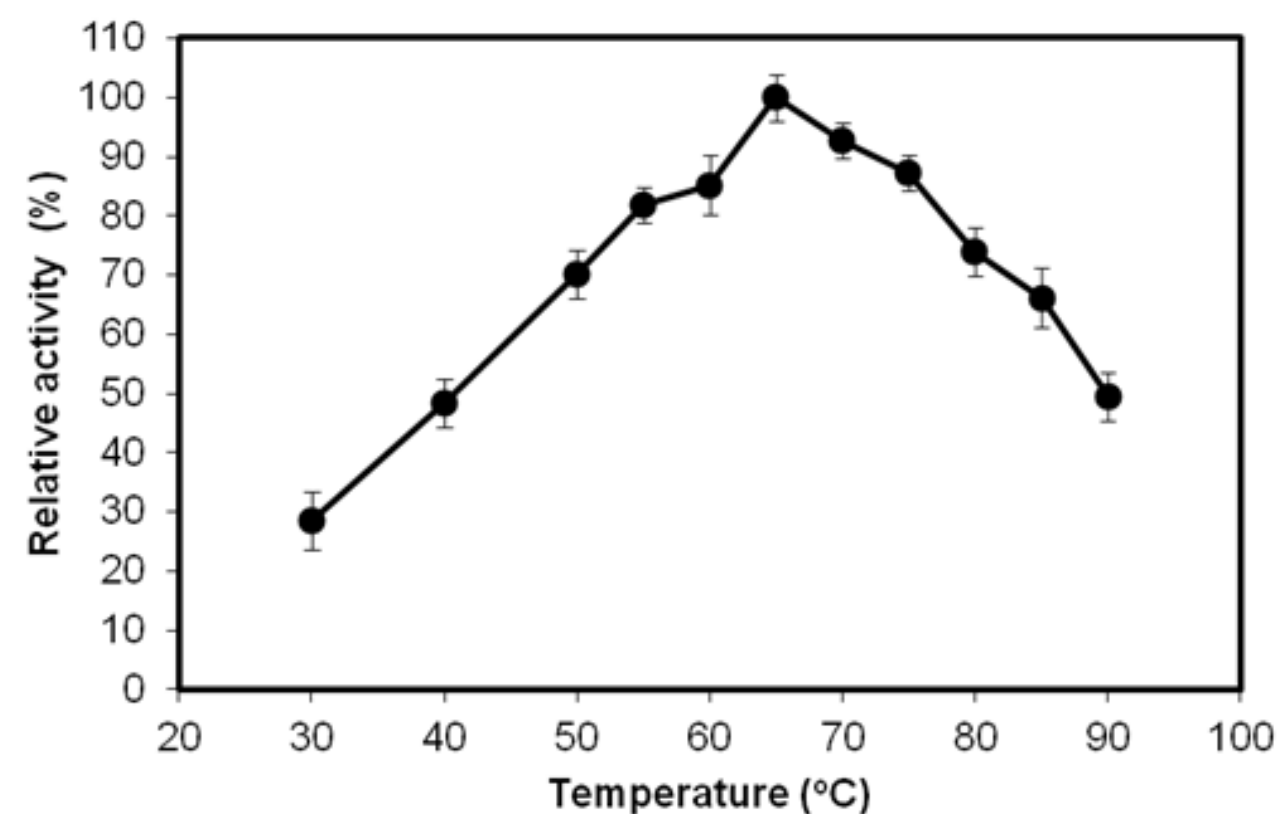

Figure 5. Effect of temperature on the purified xylanase activity. 


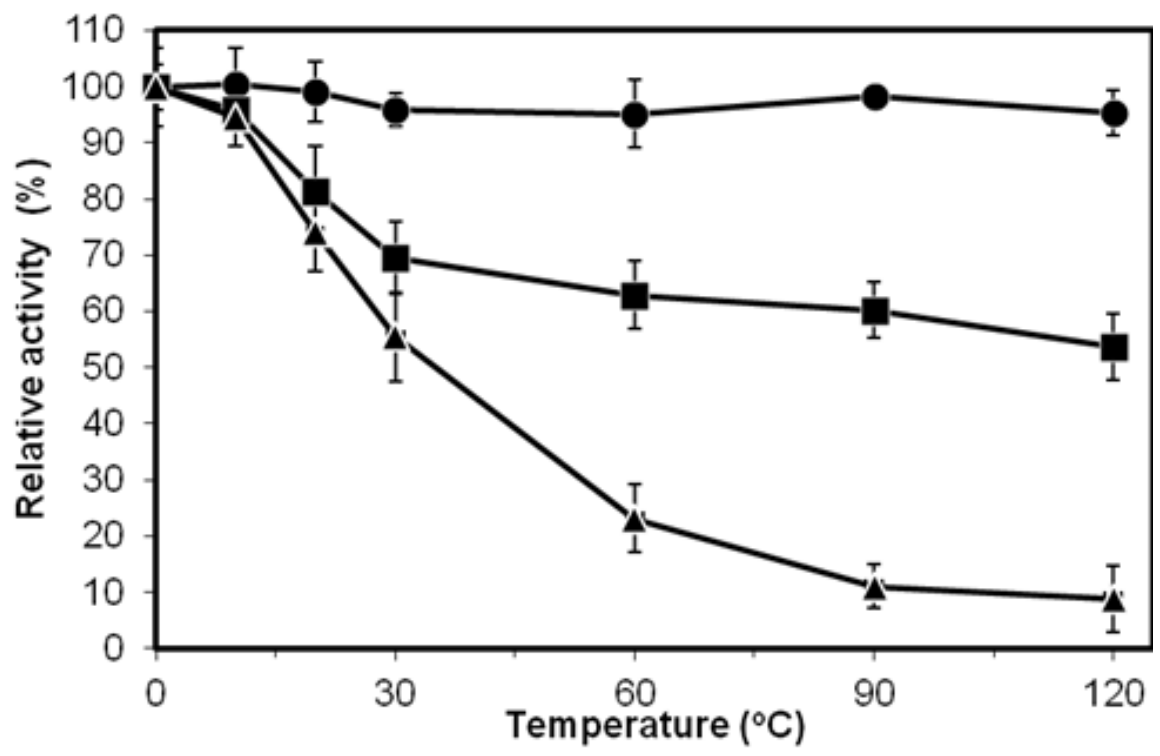

Figure 6. Thermostability profile of purified xylanase. The purified XInW31 was incubated without substrate in $100 \mathrm{mM}$ Mcllvaine buffer $(\mathrm{pH}$ 6.0) at different temperatures for $2 \mathrm{~h}$ and the residual activities were measured as described in Materials and Methods. Symbols used: solid circles, $50^{\circ} \mathrm{C}$; solid squares, $60^{\circ} \mathrm{C}$ and solid triangles, $70^{\circ} \mathrm{C}$.

Table 3. Substrate specificity of the XInW31.

\begin{tabular}{lc}
\hline Substrate $^{\mathbf{a}}$ & ${\text { Relative activity }(\%)^{\mathbf{b}}}^{\text {Birchwood xylan }}$ \\
Beechwood xylan & $81.1 \pm 3.3$ \\
Soluble oat spelt xylan & $100.0 \pm 1.6$ \\
Insoluble oat spelt xylan & $119.2 \pm 5.2$ \\
\hline
\end{tabular}

a,No activity was detected towards Avicel, carboxymethyl cellulose (CMC), glucomannan, spino gum, locust bean gum, $\mathrm{p}$-nitrophenyl- $\beta$-Dxylopyranoside, $\mathrm{p}$-nitrophenyl- $\alpha$-L-arabinofuranoside, $\mathrm{p}$-nitrophenyl- $\beta$ D-glucopyranoside; $b$,The activities of purified XInW31 towards beechwood xylan were $414.8 \mathrm{U} / \mathrm{mg}$, which was defined as $100 \%$. The results are expressed as mean \pm standard deviation from three independent experiments.

has been available regarding xylanases from thermotolerant Streptomyces, particularly an agrowastes-degrading strain. Genes encoding a xylanase and other hemicellulase activities from this strain had not previously been cloned nor had the corresponding proteins been characterized.

Hemicellulase activity, such as xylanase, $\beta$-xylosidase, $\alpha$-arabinofuranosidase and acetyl xylan esterase, was detected in the culture supernatant of Streptomyces sp. strain THW31 following growth with agriculture waste or commercially available xylan in the medium. Corn cob induced the highest xylanase, $\beta$-xylosidase and acetyl xylan esterase activities, suggesting that strain THW31 could potentially be used for the production of hemicellulase and xylooligosaccharides from agricultural
Table 4. Effect of metal ions and reagents on the XInW31.

\begin{tabular}{ll}
\hline Reagent & Relative activity (\%) \\
\hline Control & $100.0 \pm 1.6$ \\
$\mathrm{~K}^{+}$ & $99.1 \pm 0.9$ \\
$\mathrm{Li}^{+}$ & $104.2 \pm 2.2$ \\
$\mathrm{Na}^{+}$ & $109.7 \pm 3.0$ \\
$\mathrm{Ca}^{2+}$ & $96.8 \pm 2.4$ \\
$\mathrm{Co}^{2+}$ & $129.7 \pm 7.1$ \\
$\mathrm{Cu}^{2+}$ & $83.7 \pm 2.9$ \\
$\mathrm{Hg}^{2+}$ & $4.6 \pm 0.05$ \\
$\mathrm{Fe}^{2+}$ & $114.7 \pm 3.0$ \\
$\mathrm{Fe}^{3+}$ & $110.5 \pm 4.5$ \\
$\mathrm{Mg}^{2+}$ & $100.6 \pm 2.7$ \\
$\mathrm{Ni}^{2+}$ & $108.2 \pm 3.7$ \\
$\mathrm{Rb}^{2+}$ & $110.9 \pm 3.0$ \\
$\mathrm{Zn}^{2+}$ & $116.8 \pm 6.5$ \\
$\mathrm{EDTA}$ & $98.1 \pm 1.0$ \\
$\mathrm{SDS}$ & $96.9 \pm 1.0$ \\
\hline
\end{tabular}

The activities of purified XInW31 towards oat spelt xylan were $494.4 \mathrm{U} / \mathrm{mg}$, which were defined as $100 \%$. The results are expressed as mean \pm standard deviation from three independent experiments.

wastes. The data was corresponded to those of Abd ElNasser et al. (2010) and Antonopoulos et al. (2001) found that wheat straw and oat spelts xylan were the suitable carbon sources for xylanase production, respectively.

Generally, Streptomyces have been reported to be the most active producers of these enzymes and to display the most potential for the production of hemicellulases 


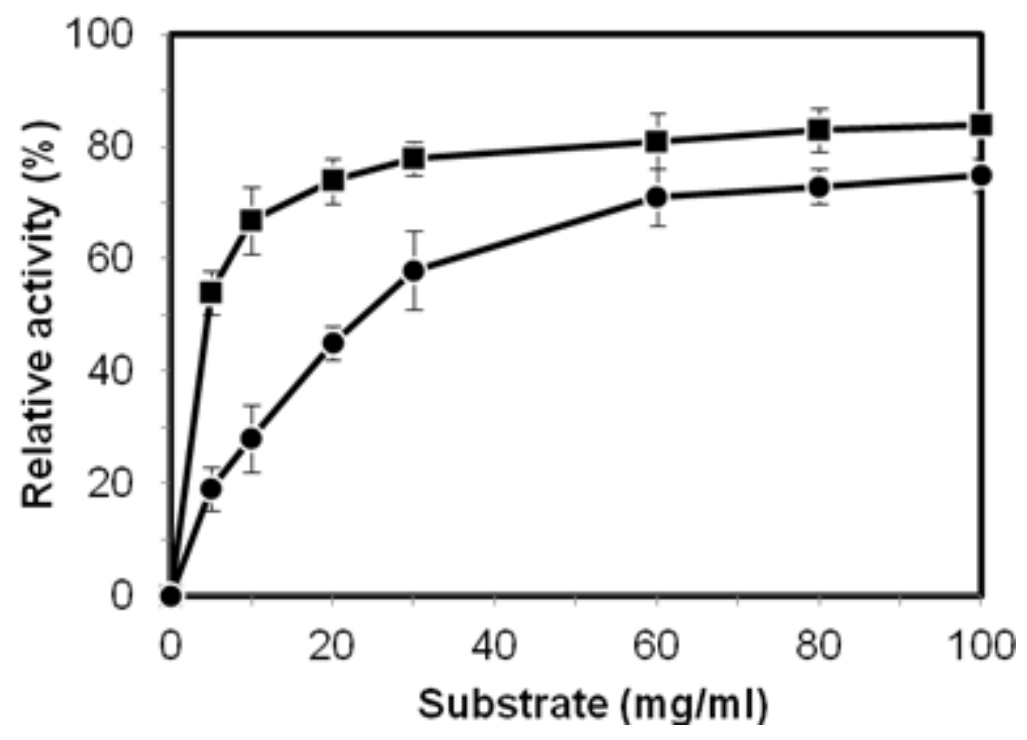

Figure 7. Binding of the purified XInW31 to insoluble oat spelt xylan and Avicel. Binding experiments were performed at $60^{\circ} \mathrm{C}$ for $1 \mathrm{~h}$. The residual activities in the supernatant were determined by as described in Materials and Methods. Symbols: solid squares, insoluble oat spelt xylan and solid circles, Avicel.

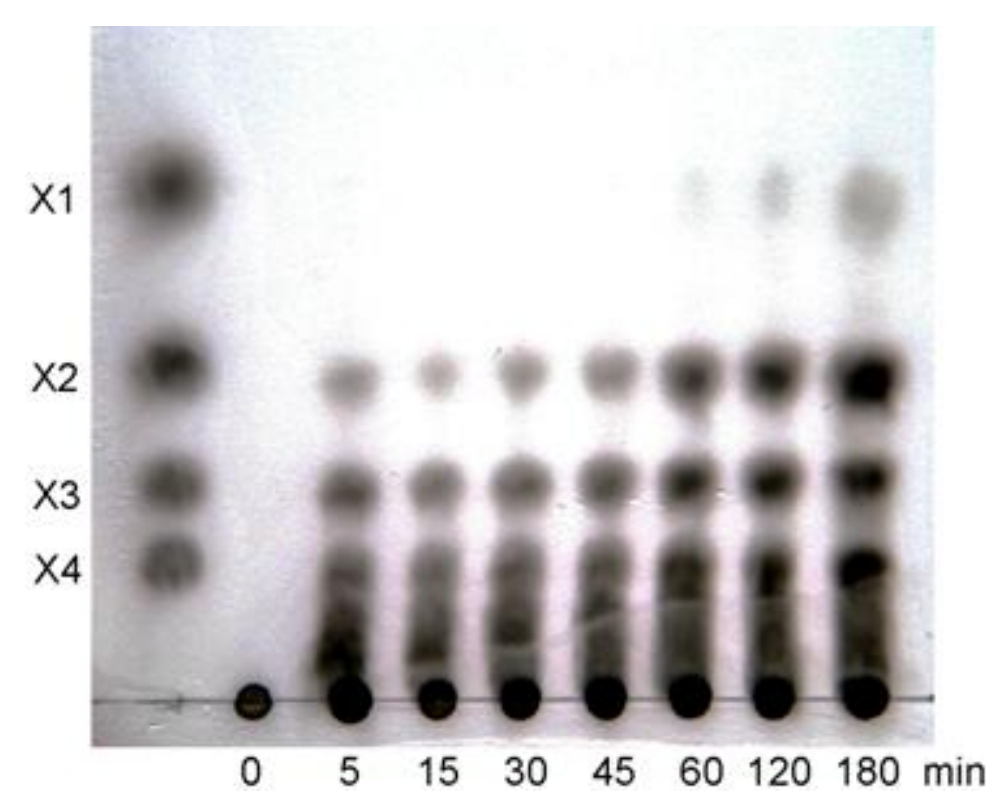

Figure 8. Xylan hydrolysis by the purified XInW31 was identified by TLC. Abbreviations used: X1, xylose; X2, xylobiose; X3, xylotriose and X4, xylotetraose.

using cheap hemicellulosic substrates from agriculture wastes, such as corn cob, rice straw and cane bagasse (Beg et al., 2000; Techapun et al., 2001; Wang et al., 2003; Ninawe and Kuhad, 2005; Abd El-Nasser et al. 2010). The content of cellulose, hemicelluloses and lignin in common agricultural residues and wastes were reported (Saha, 2003). Corncob was the best inducer because hemicelluloses are the main composition of corncob, accounting up to 30 to $35 \%$ of their dry mass. Following genomic library construction and xylanase gene identification, an ORF of 999 bp was identified and termed XInW31. The XInW31 protein contained a signal 
peptide of 41 amino acids, and the mature xylanase was 292 amino acids. According to the predicted nucleotide and amino acid sequences, XInW31 was classified into the xylanase family 11 . The mature xylanase consisted of a Gly-rich linker and a type 2 CBD. The region downstream of $x \ln W 31$ contained an ORF that was similar to acetyl xylan esterase gene (data not shown). Regions flanking the xylanase gene locus were similar to those of the known xylanase family 11 and acetyl xylan esterase genes of Streptomyces (Shareck et al., 1995; Tsujibo et al., 1997; Georis et al., 1999).

To characterize the xylanase of Streptomyces sp. THW31, a gene encoding the mature xylanase $(x \ln W 31)$ was cloned and expressed in E. coli. Although many xylanases have been cloned from Streptomyces (Techapun et al., 2003), no xylanase expression has been previously reported from the closest relatives of Streptomyces sp. THW31, including $S$. rochei, $S$. Enissocaesilis and $S$. olivaceus. An amino acid sequence comparison indicated that $\mathrm{XInW} 31$ is $90 \%$ similar to XInB from S. lividans strain 1326 (accession no. AAC06114) (Shareck et al., 1995; Kluepful et al., 1990). Both $X \ln B$ and $X \ln W 31$ have the same molecular weight $(31 \mathrm{kDa})$ but some of their enzyme characteristics were significantly different. Firstly, the optimal $\mathrm{pH}$ of $\mathrm{X} \operatorname{InB}$ and XInW31 were 6.5 and 6.0, respectively. Secondly, the optimum temperature of $X \operatorname{lnB}$ and $X \ln W 31$ were 55 and $65^{\circ} \mathrm{C}$, respectively. Despite these differences, they both displayed similar thermal stability.

Additionally, XInW31 retained more than $50 \%$ activity after pre-incubation at $70^{\circ} \mathrm{C}$ for $30 \mathrm{~min}$. Under the same condition, other family 11 xylanases, such as XLNB from S. olivaceoviridis A1 (Wang et al., 2007), XInBS27 from Streptomyces sp. S27 (Li et al., 2009), Xyl1 from Streptomyces sp. strain S38 (Georis et al., 2000) and purified xylanase from S. matensis (Yan et al., 2009), were almost inactive. The thermostability of XInW31 at $70^{\circ} \mathrm{C}$ was similar to the stability of xylanases from $S$. rameus ( $\mathrm{Li}$ et al., 2010) and Streptomyces thermocyaneoviolaceus (Shin et al., 2009). XInW31 also displayed an optimum $\mathrm{pH}$ of 6.0 and retained more than $80 \%$ activity over a pH range of 4.0 to 11.0 . This characteristic is similar to xylanases from other Streptomyces strains (Georis et al., 2000, Wang et al., 2007; Ninawe et al., 2008; Shin et al., 2009; Li et al., 2009). The broad pH profile of the $X \ln W 31$ xylanase together with its thermostability makes this enzyme an attractive candidate for industrial applications.

Upon the analysis of metal ions, $\mathrm{Co}^{2+}, \mathrm{Zn}^{2+}, \mathrm{Fe}^{2+}$ and $\mathrm{Fe}^{3+}$ have significant enhanced the effect of XInW31 activity. Previously, the above metals have been reported to enhance the xylanase activity (Yan et al., 2009). The addition of $\mathrm{Hg}^{2+}$ at $1 \mathrm{mM}$ almost completely inhibited xylanase activity while $\mathrm{Cu}^{2+}$ could partially inhibited the activity of the enzyme. Most xylanases are inhibited by sulfhydryl-enzyme inhibitors like $\mathrm{Hg}^{2+}$ and $\mathrm{Cu}^{2+}$ (Magnuson and Crawford, 1997; Li et al., 2009).
Sulfhydryl-enzyme inhibitors could modify sulfhydryl groups (thiol group) near the active site that could change the native structure of the enzyme resulting in a destabilization of enzyme folding (Rouvinen et al., 1990) or the formation of disulfide bonds at irregular position in the protein (Ohmiya et al., 1995). In addition, no significant effect on xylanase activity was observed when $1 \mathrm{mM}$ EDTA was added. This result demonstrated that the enzyme did not contain any metal ions as prosthetic groups in the active site.

Hydrolysis of xylan by XInW31, produced the major reaction product xylobiose from all of the xylan substrates that were tested (oat spelt xylan, birchwood xylan, beechwood xylan). Many member of xylanase family 11 hydrolyze xylans to xylo-oligosaccharides with the higher degree of polymerization $\geq 2$ have been reported (Kluepful et al., 1990; Yan et al., 2009; Li et al., 2009; Shin et al., 2009). This suggested that the enzyme preferentially cleave the internal glycosidic bonds of these xylo-oligosaccharides. Furthermore, XInW31 hydrolyzed both soluble and insoluble xylans and also bound to both insoluble xylan and crystalline cellulose. These results suggested that the XBD was important for insoluble xylan digestion. Usually, a xylanase that contains a XBD acts on both insoluble and soluble xylans, and previous work shows that the CBD of family 2 binds to insoluble substrates (Tsujibi et al., 1997; Shin et al., 2009).

In conclusion, the specific characteristics of recombinant XInW31 such as the broad $\mathrm{pH}$ profile, its thermostability and the efficacy of oligosaccharides production from commercial xylan and agriculture wastes, make this enzyme an attractive candidate for use in commercial production processes or industrial applications.

\section{ACKNOWLEDGEMENT}

This study is financially supported by Graduate School Srinakharinwirot University fiscal year 2012.

\section{REFERENCES}

Abd El-Nasser HN, Ali AM, Keera AA (2010). Xylanase production by Streptomyces lividans (NRC) and it's application on waste paper. Aust. J. Basic Appl. Sci. 4(6):1358-1368.

Antonopoulos VT, Hernanndez M, Arias MF, Mavrakos E, Ball AS (2001). The use ofextracellular enzymes from Streptomyces albus ATCC3005 for the bleaching of eucalyptus kraft pulp. Appl. Microbiol. Biotechnol. 27(1-2):92-97.

Beg QK, Bhushan B, Kapoor M, Hoodal GS (2000). Production and characterization of thermostable xylanase and pectinase from Streptomyces sp. QG-11-3. J. Ind. Microbiol. Biotechnol. 24:396-402.

Bailey P, Poutanen K (1992). Interlaboratory testing of methods for assay of xylanase activity. J. Biotechnol. 23:257-270.

Bailey P, Vrsanska M, Tenkanen M, Kluepfel D (1997). Endo- $\beta-1,4-$ xylanase families: differences in catalytic properties. J. Biotechnol. 57:151-166.

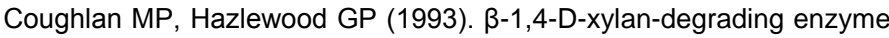
system: biochemistry, molecular biology and applications. Biotechnol. 
Appl. Biochem. 17:259-289.

Dodd D, Cann IKO (2009). Enzymatic deconstruction of xylan for biofuel production. GCB. Bioenergy 1:2-17.

Georis J, Giannotta F, Lamotte-Brasseur J, Devreese B, Beeumen JV, Granier B, Frere JM (1999). Sequence, overproduction and purification of the family 11 endo- $\beta-1,4-X y l a n a s e$ encoded by the xyl1 gene of Streptomyces sp. S38. Gene 237:123-133.

Ghangas GS, Hu YJ, Wilson DB (1989). Cloning of a Thermomonospora fusca Xylanase Gene and its Expression in Escherichia coli and Streptomyces lividans, J. Bacteriol. 171:29632969.

Gill J, Rixon JE, Bolam DN, McQueen-Mason S, Simpson PJ, Williamson MP,Hazlewood GP, Gilbert HJ (1999). The Type II and X Cellulose-Binding Domains of Pseudomonas Xylanase a Potentiate Catalytic Activity against Complex Substrates by a Common Mechanism. Biochem. J. 342:473-480.

Keiichi G, Tomoko O, Yukihiko H, Yoshito S (2000). Application of the partial 16S rDNA sequence as an index for rapid identification of species in the genus Bacillus. J. Gen. Appl. Microbiol. 46:1-8.

Kluepful D, Vats-Mehta S, Aumont F, Shareck F, Morosoli R. (1990). Purification and Characterization of new xylanase (xylanase B) produced by Streptomyces viridans 66. Biochem. J. 267:45-50.

Laemmli UK (1970). Cleavage of structural proteins during the assembly of the head of bacteriophage T4. Nature 227:680-685.

Li N, Shi P, Yang P, Wang Y, Luo H, Bai Y, Zhou Z, Yao B (2009). Cloning, expression, and characterization of a new Streptomyces sp. S27 xylanase for which xylobiose is the main hydrolysis product. Appl. Biochem. Biotechnol. 159:521-531.

Li X, She Y, Sun B, Song H, Zhu Y, Lv Y, Song H (2010). Purification and characterization of cellulase-free, thermostable xylanase from Streptomyces rameus L2001 and its biobleaching effect on wheat straw pulp. Biochem. Eng. J. 52:71-78.

Magnuson TS and Crawford DL (1997). Purification and characterization of an alkaline xylanase from Streptomyces viridosporus T7A. Enzyme Microb. Technol. 21:160-164.

Marmur $\mathrm{J}$ (1961). A procedure for the isolation of deoxyribonucleic acid from microorganisms. J. Mol. Biol. 3:208-218.

Nakamura SK, Wakabayashi K, Nakai R, Aono R, Horikoshi K (1993). Purification and some properties of an alkaline xylanase from alkaliphilic Bacillus sp. strain 41M-1. Appl. Environ. Microbiol. 59:2311-2316.

Ninawe S and Kuhad RC (2005). Use of xylan-rich cost effective agroresidues in te production of xylanase by Streptomyces cyaneus SN32. J. Appl. Microbiol. 99:1141-1148.

Ohmiya Y, Takeda T, Nakamura S, Sakai F, Hayashi T (1995). Purification and properties of a wall-bound endo-1,4- $\beta$-glucanase from suspension-cultured poplar cells. Plant Cell Physiol. 36:607-614.

Puls J (1997). Chemistry and biochemistry of hemicelluloses: Relationship between hemicelluloses structure and enzymes required for hydrolysis. Macromol. Symp. 120:183-196.

Rouvinen J, Bergfors T, Teeri T, Knowles JK, Jones TA (1990). Threedimensional structure of cellobiohydrolase II from Trichoderma reesei. Science 249:380-386.

Saha BD (2003). Hemicellulose bioconversion. J. Ind. Biotechnol. 30:279-291.

Shareck F, Biely P, Morosoli R, Kluepfel D (1995). Analysis of DNA flanking the xInB locus of Streptomyces lividans reveals genes encoding acetyl xylan. Gene 153(1):105-109.
Shin JH, Choi JH, Lee OS, Kim YM, Lee DS, Kwak YY, Kim WC, Rhee IK (2009). Thermostable xylanase from Streptomyces thermocyaneoviolaceus for optimal production of xylooligosaccharides. Biotechnol. Bioprocess Eng. 14:391-399.

Subramaniyan S, Prema P (2002). Biotechnology of microbial xylanases: enzymology, molecular biology and application. Crit. Rev. Biotechnol. 22:33-64.

Techapun C, Poosaran N, Watanabe M, Sasaki K (2003). Thermostable and alkaline-tolerant microbial cellulase-free xylanases produced from agricultural wastes and their required properties for use in pulp bleaching bioprocesses: a review. Process Biochem. 38:1327-1340.

Techapun C, Sinsuwongwat S, Poosaran N, Watanabe M, Sasaki K (2001). Production of a cellulase-free xylanase from agricultural waste materials by a thermotolerant Streptomyces sp.. Biotechnol. Lett. 23:1685-1689.

Tsujibo H, Ohtsuki T, lio T, Yamazaki I, Miyamoto K, Sugiyama M, Inamori $Y$ (1997). Cloning and sequence analysis of genes encoding xylanases and acetyl xylan esterases from Streptomyces OPC-520. Appl. Environ. Microbiol. 63:661-664.

Viikari L, Kantelinen A, Sundquist J, Linko M (1994). Xylanase in bleaching: from an idea to the industry. FEMS Microbiol. Rev. 13:335-350.

Wang SL, Yen YH, Shih IL, Chang AC, Chang WT, Wu WC, Chai YD (2003). Production of xylanases from rice bran by Streptomyces actuosus A-151. Enz. Microb. Technol. 33:917-925.

Wouters J, Georis J, Engher D, Vandenhaute J, Dusart J, Frere JM, Depiereux E, Charlier P (2001). Crystallographic analysis of family 11 endo-beta-1,4-xylanase Xyl1 from Streptomyces sp. S38. Acta. Crystallogr. D Biol. Crystallogr. 57(12):1813-1819.

Yan Q, Hao S, Jiang Z, Zhai Q, Chen W (2009). Properties of a xylanase from Streptomyces matensis being suitable for xylooligosaccharides production. J. Mol. Cat. B: Enzym. 58:72-77. 